\title{
Localization of enzymically enhanced heavy metal accumulation by Citrobacter sp. and metal accumulation in vitro by liposomes containing entrapped enzyme
}

\author{
Byeong C. Jeong, ${ }^{1}+$ Chris Hawes, ${ }^{2}$ Karen M. Bonthrone ${ }^{1}$ \\ and Lynne E. Macaskie ${ }^{1}$
}

Author for correspondence: Lynne E. Macaskie. Tel: +44 121414 5889. Fax : +44 1214146557.

1 School of Biological
Sciences, The University of
Birmingham, Edgbaston,
Birmingham B15 2TT, UK
2 School of Biological and
Molecular Sciences, Oxford
Brookes University, Gipsy
Lane, Oxford OX3 OBP, UK

\section{INTRODUCTION}

The use of micro-organisms for the accumulation of heavy metals from solution is becoming increasingly

\footnotetext{
†Present address: Department of Biological Science, College of Science, Myong Ji University, 38-2 San, Nam-ri, Yongin-eup, Yongin-gun, Kyunggido, 449-728, South Korea.
}

Abbreviations: AFM, atomic force microscopy; EDAX, energy-dispersive $X$-ray analysis; PIXE, proton-induced $X$-ray emission analysis; PNP, $p$-nitrophenol; PNPP, $p$-nitrophenyl phosphate; XRD, $X$-ray diffraction analysis.

\begin{abstract}
A heavy-metal-accumulating Citrobacter sp. has been used for the treatment of metal-laden industrial wastes. Metal uptake is mediated via a cell-bound phosphatase that liberates inorganic phosphate which precipitates with heavy metals as cell-bound metal phosphate. A phosphatase-deficient mutant accumulated little $\mathrm{UO}_{2}^{2+}$, while a phosphatase-overproducing mutant accumulated correspondingly more metal, with a uranium loading equivalent to the bacterial dry weight achieved after $6 \mathrm{~h}$ exposure of resting cells to uranyl ion in the presence of phosphatase substrate (glycerol 2-phosphate). The phosphatase, visualized by immunogold labelling in the parent and overproducing strains, but not seen in the deficient mutant, was held within the periplasmic space with, in some cells, a higher concentration at the polar regions. Enzyme was also associated with the outer membrane and found extracellularly. Accumulated uranyl phosphate was visible as cell-surface- and polar-localized deposits, identified by energy-dispersive $X$-ray analysis (EDAX), proton-induced X-ray emission analysis (PIXE) and X-ray diffraction analysis (XRD) as polycrystalline $\mathrm{HUO}_{2} \mathrm{PO}_{4} \cdot 4 \mathrm{H}_{2} \mathrm{O}$. Nucleation sites for initiation of biocrystallization were identified at the cytoplasmic and outer membranes, prompting consideration of an in vitro biocatalytic system for metal waste remediation. Phosphatidylcholine-based liposomes with entrapped phosphatase released phosphate comparably to whole cells, as shown by ${ }^{31} \mathrm{p}$ NMR spectroscopy in the presence of 'NMR-silent' ${ }^{112} \mathrm{Cd}^{2+}$. Application of liposome-immobilized enzyme to the decontamination of uranyl solutions was, however, limited by rapid fouling of the biocatalyst by deposited uranyl phosphate. It is suggested that the architecture of the bacterial cell surface provides a means of access of uranyl ion to the inner and outer membranes and enzymically liberated phosphate in a way that minimizes fouling in whole cells.
\end{abstract}

Keywords: Citrobacter sp. phosphatase, liposomes, uranium uptake attractive for the bioremediation of wastes and sites contaminated with metals. Metals can be removed from wastes upstream by biosorption (Volesky, 1990) or can be precipitated via ligands produced as a result of microbial activity. One example (Barnes et al., 1991, 1992) utilizes $\mathrm{H}_{2} \mathrm{~S}$ produced from the metabolic activity of sulphate-reducing bacteria (SRB) to precipitate metals as cell-bound metal sulphides. $\mathrm{H}_{2} \mathrm{~S}$ production is mandatory ; in the absence of this the SRB are metal-sensitive (Postgate, 1979). An alternative bioprecipitation approach has utilized the plasmid-borne metal resistance 
mechanisms of organisms such as Alcaligenes eutrophus (Mergeay et al., 1985; Diels et al., 1995). Here, heavy metals are effluxed from the cell countercurrent to proton influx inward; the ensuing localized alkalinization of the periplasmic space promotes deposition of heavy metals as hydroxides and carbonates in the cellular micro-environment. Both of these examples rely on continuing metabolic activity, which may be sensitive to adverse physical conditions such as the $\mathrm{pH}$ of the target waste stream and the toxicity of other cocontaminants. In this respect the use of non-growing (growth-decoupled) biomass may be necessary for prolonged activity and to overcome the constraints imposed by the waste stream.

Although the reductive bioprecipitation and removal of metal anions via growth-decoupled hydrogenase activity of SRB and of Escherichia coli has been documented (Lloyd \& Macaskie, 1996; Lloyd et al., 1997; Macaskie et al., 1996), the use of non-growing cells for removal of metals by biocrystallization via a single enzymic step has received relatively little attention. In addition to a reduced dependence on physiologically permissive conditions (the sensitivity is limited to the enzyme catalysing ligand production), the use of growth-decoupled cells produces a sludge which is compact and attractive in terms of the low organic content and high enrichment for the metal for recycling.

The most extensively documented example of growthdecoupled metal removal is by a strain of Citrobacter $\mathrm{sp}$. originally isolated from metal-contaminated soil (Macaskie, 1990; Macaskie et al., 1992, 1995a; Yong \& Macaskie, 1995; Tolley et al., 1995). This organism has been applied to the removal of uranium from mine water (Roig et al., 1995; Macaskie et al., 1996, 1997) and to the accumulation of radiotoxic elements such as americium and plutonium (Macaskie et al., 1994a, 1996). Metal uptake requires a cellular phosphatase, homologous to the phoN product of Salmonella and some other enterobacteria (Macaskie et al., 1994b), which liberates inorganic phosphate from a supplied organic phosphate substrate to precipitate $\mathrm{HPO}_{4}^{2-}$ with metals $(\mathrm{M})$ extensively as cell-bound $\mathrm{MHPO}_{4}$ (Macaskie et al., 1992, 1996; Tolley et al., 1995; Yong \& Macaskie, 1995). However, little is known of the cellular localization of this phosphatase in vivo and the mechanism(s) by which enzymic activity contributes to the metal bioaccumulation process. Factors other than phosphate release alone are implicated in effective metal removal (Macaskie et al., 1995a); indeed, some other enterobacteria containing phoN removed little heavy metal from solution (Macaskie et al., 1994b).

A previous study indicated that the acid phosphatase of Salmonella typhimurium was not released easily by osmotic shock (Neu \& Heppel, 1965; Nossal \& Heppel, 1966; Kier et al., 1977). The Citrobacter enzyme was, similarly, poorly extracted (Jeong, 1992) in conflict with a proposed role for the enzyme in the accumulation of heavy metals within the periplasmic space. Immobilized phosphatase removed little metal from solution per se
(B. C. Jeong, unpublished) and previous studies suggested a requirement for nucleation sites for initiation of crystal growth (Macaskie et al., 1996). This study aims to identify the site(s) of phosphatase localization, relative to the site(s) of metal uptake. Nucleation sites were suggested on the membrane phospholipid groups. Therefore, an in vitro system was constructed using artificial membrane vesicles (liposomes) with entrapped phosphatase to evaluate a possible application of the encapsulated enzyme for metal removal in vitro. This could forestall potential problems (e.g. biofouling) associated with the use of live bacteria in filtration systems and gain acceptability if genetic manipulation was employed to increase the level of phosphatase production further.

\section{METHODS}

Bacterial strains and growth conditions. Citrobacter sp. strain N14, originally isolated from metal-polluted soil, was as described previously (Macaskie et al., 1992, 1996; Tolley et al., 1995; Yong \& Macaskie, 1995), by permission of Isis Innovation, Oxford. The phosphatase-overproducing (dc5c) and-deficient (lp4a) mutants were as described previously (Macaskie, 1995; Macaskie et al., 1988). The cultures $(250 \mathrm{ml}$ $-3 \mathrm{l}$ as appropriate) were grown at $30^{\circ} \mathrm{C}$ in a Tris/glycerol 2phosphate-based minimal medium with glycerol $\left(2 \mathrm{~g} \mathrm{l}^{-1}\right)$ as the carbon source and forced aeration (Tolley et al., 1995). For phosphatase preparation cultures were grown as above in two 151 batches or in larger batches of 1001 in an adapted 1301 plastic drum. This was sterilized using propylene oxide under ambient conditions for $7 \mathrm{~d}$ with residual gaseous sterilant displaced with sterile air for several days. The culture was grown at $30{ }^{\circ} \mathrm{C}$ from an approximately $2 \%(\mathrm{v} / \mathrm{v})$ overnight culture inoculum using an overhead stirrer and forced aeration, and harvested at ambient temperature (continuous flow centrifuge: Heraeus 17RS). Large quantities of enzyme for entrapment within liposomes or for studies using NMR were prepared from cultures $(600 \mathrm{l})$ grown in an LSL Biolafitte bioreactor in the Centre for Biochemical Engineering, University of Birmingham, in glycerol-based medium (Macaskie et al., 1995b).

Purification of phosphatase and assay of phosphatase activity. Cell disruption was achieved using a French pressure cell (SLMO AMINCO, SLM instruments Co.) or a cell disruptor ('Bio Neb' cell disruptor, Glas-Col Ltd) for the biomass harvested from the 6001 culture. The phosphatase was purified via $\left(\mathrm{NH}_{4}\right)_{2} \mathrm{SO}_{4}$ fractionation, anion and cation exchange column chromatography and fractionation on hydroxyapatite and phenyl-Sepharose columns (Jeong, 1992; Jeong et al., 1994), and was judged as pure by a single band on SDS-PAGE (Jeong, 1992). Phosphatase activity was assayed by the release of $p$-nitrophenol (PNP) from $p$-nitrophenyl phosphate (PNPP) (Tolley et al., 1995; Macaskie et al., $1995 \mathrm{a}, \mathrm{b})$. One unit of activity is defined as that liberating $1 \mathrm{nmol}$ product $\mathrm{min}^{-1}$ (mg bacterial protein $)^{-1}$, with protein assayed by the Lowry method and calculated from the $\mathrm{OD}_{600}$ of the bacterial suspension via a conversion factor (Jeong, 1992). The molar extinction coefficient for PNP was $9025 \mathrm{~cm}^{-1} \mathrm{M}^{-1}$, measured under the conditions of assay $(1 \mathrm{~cm}$ path length; $A_{410}$ ).

Immobilized phosphatase column. Purified phosphatase was immobilized onto cyanogen bromide (CNBr)-activated Sepharose CL-4B (all steps at $4^{\circ} \mathrm{C}$ ). CNBr-activated Sepharose CL4B ( $2 \mathrm{ml}$; Sigma) was added to $0.5 \mathrm{ml}$ phosphatase $\left(8 \mathrm{mg} \mathrm{ml}^{-1}\right)$ 
in $0.5 \mathrm{M}$ sodium phosphate buffer, $\mathrm{pH} 7.5$, and gently mixed overnight. The beads were washed twice with the phosphate buffer, then once with $0.05 \mathrm{M}$ sodium phosphate buffer, $\mathrm{pH}$ $7 \cdot 5$, supplemented with $1 \mathrm{M} \mathrm{NaCl}$. Ethanolamine buffer $(0.1 \mathrm{M}, \mathrm{pH} 7.5,10$ times the volume of the beads) was added and the mixture gently mixed at $30^{\circ} \mathrm{C}$ for $4 \mathrm{~h}$. The beads were washed twice with PBS $\left\langle 1^{-1}: 8.0 \mathrm{~g} \mathrm{NaCl}, 0.2 \mathrm{~g} \mathrm{KCl}, 1.44 \mathrm{~g}\right.$ $\mathrm{Na}_{2} \mathrm{HPO}_{4}, 0.24 \mathrm{~g} \mathrm{~K}_{2} \mathrm{HPO}_{4}, \mathrm{pH} 7 \cdot 2$ ) and placed in a disposable column with a bed volume of $1.5 \mathrm{ml}$ (Pierce) and washed with $0.01 \mathrm{M}$ Tris/ $\mathrm{HCl}$ buffer $(15 \mathrm{ml}, \mathrm{pH} 7.5), 0.1 \mathrm{M}$ glycine $/ \mathrm{HCl}$ buffer (15 ml, pH 2.5), 0.01 M Tris/HCl buffer (15 ml, pH 8.8) and finally $0.1 \mathrm{M}$ freshly prepared diethylamine/ $\mathrm{HCl}$ buffer $(15 \mathrm{ml}, \mathrm{pH} 11.5)$ followed by $0.01 \mathrm{M}$ Tris/ $\mathrm{HCl}$ buffer $(15 \mathrm{ml}$, $\mathrm{pH} 7.5)$. After use the column was washed with $0.01 \mathrm{M}$ Tris/ $\mathrm{HCl}$ buffer $(15 \mathrm{ml}, \mathrm{pH} 7.5)$ and stored at $4{ }^{\circ} \mathrm{C}$ in this buffer supplemented with $0.01 \%(\mathrm{w} / \mathrm{v})$ merthiolate (Sigma).

Preparation of phosphatase antibody and ELISA. Purified phosphatase (1 ml, $4 \mathrm{mg}$ ) in PBS was mixed with $1 \mathrm{ml}$ Freund's complete adjuvant (Sigma) and emulsified by passing through two 10-gauge needles until the emulsion was thick and did not disperse when a drop was placed on the surface of PBS. Blood $(10 \mathrm{ml})$ was collected from two female rabbits (New Zealand White; University of Oxford) which were injected subcutaneously with a $500 \mu \mathrm{g}$ protein sample. A boost was given in Freund's incomplete adjuvant (Sigma) after 4 weeks with subsequent boosts at 2-week intervals. Blood samples were allowed to clot for $1 \mathrm{~h}$ at $30^{\circ} \mathrm{C}$, then overnight at $4{ }^{\circ} \mathrm{C}$, and the serum was centrifuged $\left(6600 \mathrm{~g}, 10 \mathrm{~min}, 4^{\circ} \mathrm{C}\right)$. The crude antibody solution was stirred at $4{ }^{\circ} \mathrm{C}$ with 0.5 vols saturated $\left(\mathrm{NH}_{4}\right)_{2} \mathrm{SO}_{4}\left[761 \mathrm{~g}\left(\mathrm{NH}_{4}\right)_{2} \mathrm{SO}_{4}\right.$ in 1 litre distilled water] added slowly and left unstirred for $2 \mathrm{~h}$ at $4{ }^{\circ} \mathrm{C}$, followed by centrifugation $\left(19300 \mathrm{~g}, 20 \mathrm{~min}, 4^{\circ} \mathrm{C}\right)$. Saturated $\left(\mathrm{NH}_{4}\right)_{2} \mathrm{SO}_{4}$ $(0.5$ vols of the starting volume) was added to the supernatant. After $4 \mathrm{~h}$ at $4{ }^{\circ} \mathrm{C}$ the preparation was centrifuged $(19300 \mathrm{~g}$, $20 \mathrm{~min}, 4^{\circ} \mathrm{C}$ ). The pellet was resuspended in PBS (volume equal to the starting volume), dialysed against four changes of PBS (50 vols of the antibody solution) overnight at $4{ }^{\circ} \mathrm{C}$ and centrifuged $(13700 \mathrm{~g}, 10 \mathrm{~min}$, ambient temperature). Samples $(1 \mathrm{ml})$ were passed through the phosphatase affinity column three times, under gravity. The column was washed with $0.01 \mathrm{M}$ Tris/ $\mathrm{HCl}$ buffer $(20 \mathrm{ml}, \mathrm{pH} 7.5)$ and then $20 \mathrm{ml}$ of the same buffer supplemented with $500 \mathrm{mM} \mathrm{NaCl}$. The antibody bound by acid-sensitive interactions was eluted with $0 \cdot 1 \mathrm{M}$ glycine/ $\mathrm{HCl}$ buffer $(15 \mathrm{ml}, \mathrm{pH} 2.5)$ into a tube containing $1 \mathrm{M}$ Tris/ $\mathrm{HCl}$ buffer $(1.5 \mathrm{ml}, \mathrm{pH} 8.0)$. The column was then washed with $0.01 \mathrm{M}$ Tris $/ \mathrm{HCl}$ buffer $(15 \mathrm{ml}, \mathrm{pH} 8.8)$. The antibody bound by base-sensitive interactions was eluted with $0 \cdot 1 \mathrm{M}$ freshly prepared diethylamine/ $\mathrm{HCl}$ buffer $(15 \mathrm{ml}, \mathrm{pH}$ $11.5)$ into a tube containing $1 \mathrm{M}$ Tris/ $\mathrm{HCl}$ buffer $(1.5 \mathrm{ml}, \mathrm{pH}$ 8.0). Fractions were assayed using ELISA (see below), pooled and dialysed against four changes of PBS (50 vols of the antibody fractions) overnight. For ELISA, $50 \mu \mathrm{l}$ phosphatase $\left(10 \mu \mathrm{g} \mathrm{ml}^{-1}\right.$ solution in PBS) was added to wells of a microtitre plate and left for $2 \mathrm{~h}$ at ambient temperature in a humid atmosphere, washed three times (PBS), dried by inversion and washed three times with blocking buffer $[3 \%(w / v)$ non-fat dried milk (Marvel) in PBS]. Primary antibody solution (serum or column eluate: $50 \mu \mathrm{l}$ ) was added to each well, incubated and washed as described above. Horseradish peroxidase (HRP)-labelled goat anti-rabbit antibody $(50 \mu$ of a $1: 1000$ dilution; Dakopatts, supplied by Agar Scientific Ltd) was added, incubated and washed as above. Dilutions of primary and secondary antibody were done in blocking buffer. For detection, chromogenic substrate for HRP $\left[0 \cdot 1 \mathrm{mg} 3^{\prime}, 3^{\prime}, 5^{\prime}, 5^{\prime}-\right.$ tetramethylbenzidine (TMB); Sigma] was dissolved in $0.1 \mathrm{ml}$ DMSO. Sodium acetate buffer $(0 \cdot 1 \mathrm{M}, \mathrm{pH} 6.0,9 \cdot 9 \mathrm{ml})$ was added, the mixture was filtered through a $0.22 \mu \mathrm{m}$ filter (Millipore) and $30 \% \mathrm{H}_{2} \mathrm{O}_{2}$ (Sigma) was added to a final concentration of $0.01 \%(\mathrm{v} / \mathrm{v})$. Substrate solution $(50 \mu \mathrm{l})$ was added to each well and left for $15 \mathrm{~min}$ at ambient temperature. The reaction (pale blue positive) was stopped by addition of $50 \mu \mathrm{l} 1 \mathrm{M} \mathrm{H}_{2} \mathrm{SO}_{4}$ (bright yellow positive). The titre of the serum or column eluate was defined as the highest dilution to give a negative reaction against controls with no enzyme or primary antibody.

\section{Fixation and embedding of cells for electron microscopy}

Fixation and embedding for cell staining. All steps were at ambient temperature unless otherwise stated. Cells $(30 \mathrm{ml})$ harvested by centrifugation $(5000 \mathrm{~g}, 10 \mathrm{~min})$ in the midexponential phase were resuspended in $0.1 \mathrm{M}$ sodium cacodylate buffer $(1.5 \mathrm{ml}, \mathrm{pH} 7 \cdot 2)$ with $2 \%(\mathrm{w} / \mathrm{v})$ sucrose, fixed for $40 \mathrm{~min}$ in an equal volume of $2 \%(\mathrm{v} / \mathrm{v})$ glutaraldehyde and $2 \%(\mathrm{w} / \mathrm{v})$ paraformaldehyde in the same buffer and washed three times (10 min each) in $1 \mathrm{ml}$ of the same buffer without fixatives. Osmium tetroxide $(1 \mathrm{ml}, 1 \% \mathrm{w} / \mathrm{v}$, aq. $)$ was then added. After $1 \mathrm{~h}$ the mixture was centrifuged $(5000 \mathrm{~g}, 10 \mathrm{~min}$ ), the pellet was washed in $1 \mathrm{ml}$ distilled water, incubated overnight at $4{ }^{\circ} \mathrm{C}$ in $1 \mathrm{ml}$ uranyl citrate $(0.5 \% \mathrm{w} / \mathrm{v}$, aq.) and dehydrated with $10,20,30,50,70$ and $90 \%$ (v/v, aq.) ethanol for 10-20 min each followed by absolute ethanol twice. Embedding was in absolute ethanol/Spurr (TAAB Laboratory Equipment Ltd) at ratios of $3: 1,1: 1$ and $1: 3(\mathrm{v} / \mathrm{v})$ for $1 \mathrm{~h}$ each, and three changes of undiluted Spurr $(1,12$ and $12 \mathrm{~h}$, respectively). Samples were transferred from Eppendorf tubes to silicone rubber moulds (Agar Scientific Ltd) to polymerize for $10 \mathrm{~h}$ at $70^{\circ} \mathrm{C}$.

Low temperature embedding in LR White. Benzoin methyl ether (Aldrich) was added to LR White (final concentration $0.5 \%$ w/v; Agar Scientific Ltd) to accelerate hardening. Cells were resuspended in $0 \cdot 1 \mathrm{M}$ PIPES buffer $(1.5 \mathrm{ml}, \mathrm{pH} \mathrm{7.2})$, fixed and washed as above, then dehydrated in 10 and $20 \%$ (v/v, aq.) ethanol at ambient temperature (10 min each), and in $30 \%$ ethanol at $0{ }^{\circ} \mathrm{C}$ and $50 \%$ ethanol at $-20^{\circ} \mathrm{C}(1 \mathrm{~h}$ each $)$. Further dehydration used $70 \%, 90 \%$ and absolute ethanol at $-20^{\circ} \mathrm{C}$ (1 h each). Embedding was in LR White/absolute ethanol at ratios of $1: 1,2: 1$ and $3: 1(\mathrm{v} / \mathrm{v})$ at $-20^{\circ} \mathrm{C}$ for $1 \mathrm{~h}$ each, followed by four changes of undiluted LR White at $-35^{\circ} \mathrm{C}$ (overnight, $8 \mathrm{~h}$, overnight and $8 \mathrm{~h}$, respectively). Polymerization $\left(12 \mathrm{~h}\right.$ at $-20^{\circ} \mathrm{C}$ and $12 \mathrm{~h}$ at $\left.4^{\circ} \mathrm{C}\right)$ was done using a UV lamp (Agar Scientific Ltd).

Thin sectioning and mounting of sections. Cells embedded in Spurr or LR White were thin-sectioned $(80-100 \mathrm{~nm})$ with a glass knife using a Reichert-Jung Knifemaker and a microtome (Ultracut E, Reichert-Jung). Sections from the normal fixation and embedding in Spurr were mounted on $\mathrm{Cu}$ grids (Agar Scientific Ltd) and stained with lead citrate for observation of cell structure. Sections from the low temperature embedding in LR White were mounted on Formvarcoated Ni grids (Agar Scientific Ltd) for enzyme localization (see below).

Immunogold labelling. This was done at room temperature with reagents filtered through a $0 \cdot 22 \mu \mathrm{m}$ sterile filter (Millipore) prior to use. Sections of LR White-embedded cells were blocked with PBSBT [PBS containing $1 \%$ (w/v, aq.) globulinfree bovine serum albumin (PBSB : BSA from Sigma) and $0.2 \%$ (v/v, aq.) Tween $80, \mathrm{pH} 6.9$ (Sigma)] for $10 \mathrm{~min}$, then with PBSBG [PBS containing $1 \%(\mathrm{w} / \mathrm{v}$, aq.) globulin-free BSA and $0.02 \mathrm{M}$ final concentration glycine, $\mathrm{pH} 6.9$ (Sigma)] for $5 \mathrm{~min}$. Sections were washed four times ( $5 \mathrm{~min}$ each) by floating the grid upside down on a droplet of PBSB solution. The grids 


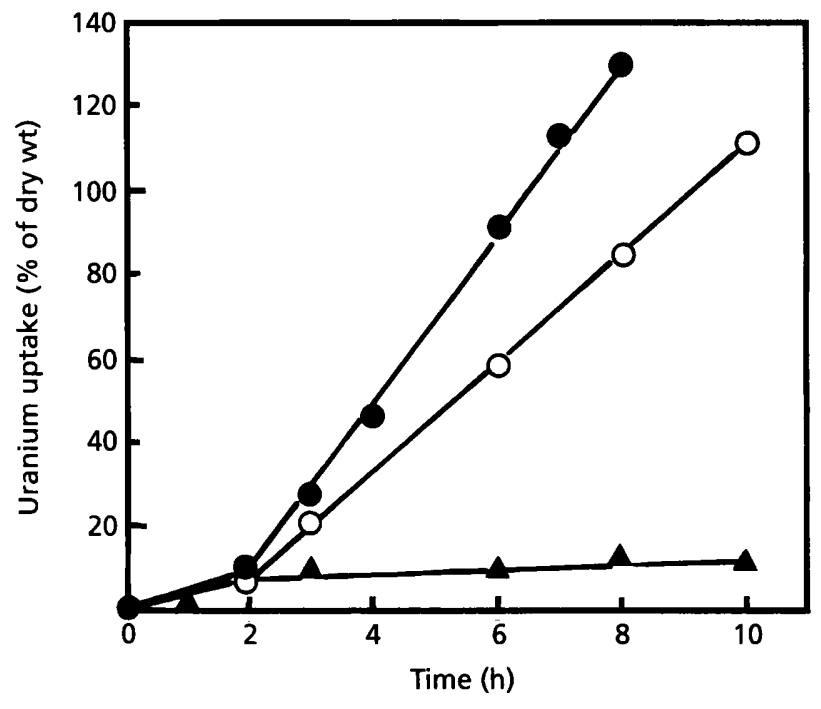

Fig. 1. Uranyl ion uptake by the phosphatase-deficient mutant Ip4a (A, specific activity 18 units), the phosphataseoverproducing mutant dc5c (O, specific activity 847 units) and the parent strain N14 (O, phosphatase specific activity 396 units). Cells were harvested in the late exponential phase and resuspended in challenge solution supplemented with $1 \mathrm{mM}$ $\mathrm{UO}_{2}^{2+}$ (see Methods). Data are from a representative experiment.

were incubated on a primary antibody droplet $(15 \mu \mathrm{g}$ rabbit anti-phosphatase $\mathrm{ml}^{-1}$ in PBSB) for $1 \mathrm{~h}$ in a damp box, washed twice (5 min each) in PBSBT and once in PBSBG (5 min), then incubated with gold $(10 \mathrm{~nm})$-labelled goat anti-rabbit antibody (1:20 dilution in PBSB; British Biocell) for $1 \mathrm{~h}$. The grids were washed three times ( $3 \mathrm{~min}$ each) in PBSB and three times ( $1 \mathrm{~min}$ each) in distilled water. For low phosphatase activity cells in some experiments, the concentrations of primary antibody and secondary antibody were increased to $75 \mu \mathrm{g} \mathrm{ml}^{-1}$ and $1: 10$ dilution, respectively. The sections were stained with a drop of $0.5 \%$ (w/v, aq.) uranyl citrate (10-30 min), washed three times ( $1 \mathrm{~min}$ each) in distilled water and examined with a JEOL 1200 EX 11 transmission electron microscope with an accelerating voltage of $80 \mathrm{keV}$, or as otherwise stated.

Determination of metal removal by resuspended cells. Cells harvested in the exponential phase $(20-40 \mathrm{ml})$ were washed twice in isotonic saline $\left(8.5 \mathrm{~g} \mathrm{NaCl}^{-1}\right)$ and resuspended $\left(\mathrm{OD}_{600} 0.3-0.4\right)$ in $2 \mathrm{mM}$ citrate buffer, $\mathrm{pH} 6.9,5 \mathrm{mM}$ glycerol 2-phosphate, with the addition of uranyl nitrate to $1 \mathrm{mM}$ at $30^{\circ} \mathrm{C}$. Timed samples $(1.25 \mathrm{ml})$ were centrifuged $(13700 \mathrm{~g}$, $5 \mathrm{~min}$, ambient temperature) and the supernatants assayed for residual uranyl ion (Tolley et al., 1995). Uranium removal was calculated as a percentage of bacterial dry weight using a dry weight calibration of $0.495 \mathrm{mg} \mathrm{ml}^{-1}$ for 1 unit of $\mathrm{OD}_{600}(1 \mathrm{~cm}$ path length; P. Yong \& L. E. Macaskie, unpublished). The uranium-loaded cell pellets (each equivalent to $5 \mathrm{ml}$ culture) were washed twice in isotonic saline and once in water, resuspended in $0.2-0.4 \mathrm{ml}$ water and mixed, and a drop was placed on a Formvar-coated electron microscope grid, airdried overnight and examined with the electron microscope without further staining. For monitoring the intracellular uranium accumulation, uranium-loaded cells (equivalent to $5 \mathrm{ml}$ culture) were washed twice in isotonic saline and water, fixed and embedded in LR White as described above and thin sections $(80-100 \mathrm{~nm})$ were examined, without further staining.
Preparation of liposomes with entrapped phosphatase, phosphate release and metal uptake. Phosphatidylcholine (25 mg), cholesterol (2 mg) and stearic acid (1 mg) were dissolved in $10 \mathrm{ml}$ chloroform/methanol $(9: 1, \mathrm{v} / \mathrm{v})$. The solvent was evaporated under vacuum at room temperature. Phosphatase $(2.5 \mathrm{ml}, 4.8 \mathrm{mg}$ ) in $20 \mathrm{mM}$ MOPS buffer, $\mathrm{pH} 7$, and six glass beads $(2.5 \mathrm{~mm}$ diam.) were added and the flask agitated to mix. The flask was flushed with $\mathrm{N}_{2}$ and sonicated $(36 \mathrm{~Hz}, 6 \times 30 \mathrm{~s})$ and the liposomes were centrifuged $(80000 \mathrm{~g}, 20 \mathrm{~min})$. The supernatant (untrapped enzyme) was removed and the liposomes were resuspended in $2.5 \mathrm{ml}$ MOPS buffer (20 mM, pH 7) and re-centrifuged. The supernatant was tested for residual free enzyme using PNPP. In some experiments the phosphatase was used after only the anion and cation exchange purification steps. Only minor contaminants remained at this stage. For assay, liposome-entrapped enzyme $[0.08 \mathrm{ml}$ liposome preparation of phosphatase; specific activity $980 \mathrm{nmol}$ PNP $\left.\min ^{-1}(\mathrm{mg} \text { protein })^{-1}\right]$ was added to $0.72 \mathrm{ml}$ MOPS buffer (20 mM, pH 7) and $0.2 \mathrm{ml}$ glycerol 2phosphate (final concentration $1 \mathrm{mM}$ ) at $30^{\circ} \mathrm{C}$. Samples were analysed for liberated phosphate $\left(P_{1}\right)$ in supernatants by a modification of the method of Pierpoint (1957). Where appropriate, $\mathrm{Cd}^{2+}$ or $\mathrm{UO}_{2}^{2+}$ were added as the nitrate salts (final concentration $1 \mathrm{mM}$ ). Residual uranyl ion was assayed (Tolley et al., 1995) following removal of the liposomes by centrifugation as above.

Examination of phosphate release using NMR. Solution ${ }^{31} \mathrm{P}$ NMR was performed using a Bruker $400 \mathrm{MHz}$ Spectrometer at $161 \mathrm{MHz}$ with a pulse time of $0.91 \mu$ s and a pulse recycle delay of $1 \mathrm{~s} . \mathrm{H}_{3} \mathrm{PO}_{4}(85 \%, v / v)$ was used as a standard and $\mathrm{D}_{2} \mathrm{O}$ as a field frequency lock. Liposome preparations, as described above, with or without $1 \mathrm{mM} \mathrm{Cd}^{2+}$, were incubated in an NMR tube. Initial experiments using $1 \mathrm{mM}$ glycerol 2phosphate (see above) were below the sensitivity of NMR; subsequent experiments therefore utilized $5 \mathrm{mM}$ glycerol 2 phosphate.

Examination of metal-loaded cells and liposomes using solidstate methods. Whole cells, sectioned cells (above) and liposomes were examined by electron microscopy (EM), atomic force microscopy (AFM), energy-dispersive X-ray analysis (EDAX), proton-induced X-ray emission (PIXE) analysis and X-ray diffraction analysis (XRD), as appropriate. For EM the liposomes were resuspended in water, dropped onto a copper electron microscope grid, air-dried and examined using the transmission electron microscope (JEOL). AFM was done using wet or briefly air-dried mounts in water on glass slides in the laboratories of the Company Research Laboratory, BNFL, Preston, UK. The accumulated solid material was characterized using EDAX and PIXE as described previously (Bonthrone et al., 1996; Tolley et al., 1995; Yong \& Macaskie, 1995), and the identity of the deposit was confirmed by XRD (Bonthrone et al., 1996; Yong \& Macaskie, 1995) and comparison with appropriate reference databases (Bonthrone et al., 1996).

\section{RESULTS AND DISCUSSION}

\section{Phosphatase activity and uranyl ion accumulation by Citrobacter sp. strain N14 and mutants with altered enzyme activity}

The phosphatase deficiency of strain lp4a (specific activity 12-18 units) was confirmed by immunogold labelling. No phosphatase was visible in the mutant under conditions where the parent strain, N14, clearly expressed the enzyme. The low specific activity 
Table 1. Comparison of uranium removal efficiency and phosphatase activity of Citrobacter N14 and the phosphatase-overproducing strain dc5c

Data are shown for resting cells obtained from batch cultures as shown and challenged with $1 \mathrm{mM}$ uranyl nitrate as described in Methods.

\begin{tabular}{|llc|}
\hline Sample & \multicolumn{2}{c|}{ Uranium removal efficiency (phosphatase specific activity)* } \\
\cline { 2 - 3 } & \multicolumn{1}{c|}{ N14 } & dc5c \\
\hline Exponential phase & $12.3 \pm 1 \cdot 4(421 \pm 71)$ & $19 \cdot 9 \pm 2 \cdot 4(675 \pm 164)$ \\
Stationary phase & $16.0 \pm 1.8(587 \pm 80)$ & $22.9 \pm 1.0(1089 \pm 339)$ \\
\hline
\end{tabular}

Uranium removal efficiency is shown as percentage of the bacterial dry $w t h^{-1}$. See Methods for a definition of the units of phosphatase specific activity.
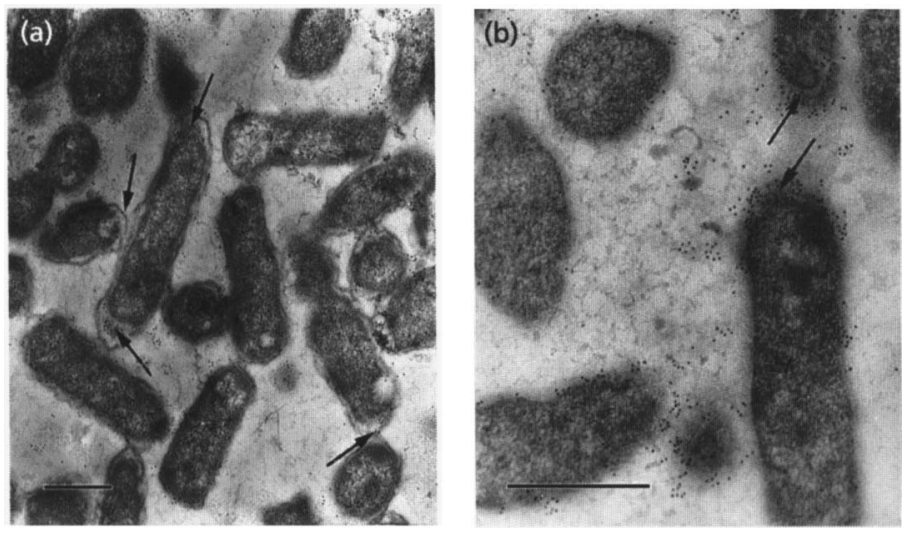

\begin{abstract}
Fig. 2. Localization of phosphatase in strains N14 (a) and dc5c (b). Cells were fixed and embedded as described in Methods. Sections $(80-100 \mathrm{~nm})$ were reacted with rabbit antiphosphatase antibody (primary antibody, $15 \mu \mathrm{g} \mathrm{ml}^{-1}$ ) and gold-labelled goat antirabbit antibody (secondary antibody, 1:20 dilution of that supplied). Sections were stained with $0.5 \%$ uranyl citrate and examined with an accelerating voltage of $80 \mathrm{keV}$. Strain $\mathrm{N} 14$ was harvested at $\mathrm{OD}_{600}=$ 0.94 with a phosphatase specific activity of 272 units. Strain $\mathrm{dc} 5 \mathrm{c}$ was harvested at $\mathrm{OD}_{600}$ $=0.95$ with a phosphatase specific activity of 946 units. Representative samples are shown. Bars, $500 \mathrm{~nm}$.
\end{abstract}

corresponded to poor removal of uranyl ion, where the parent strain accumulated $\mathrm{UO}_{2}^{2+}$ to $>100 \%$ of the bacterial dry weight after $10 \mathrm{~h}$ (Fig. 1). Conversely, the phosphatase-overproducing mutant, $\mathrm{dc} 5 \mathrm{c}$, showed an increased rate of uranyl ion uptake in a typical experiment (Fig. 1). This increase, less than two-fold in the example shown (despite a two-fold difference in phosphatase activity), was probably because at high phosphatase activities (above 700 units) the rate of $P_{i}$ liberation ceases to be rate-limiting and biocrystallization constraints may prevail (Macaskie et al., 1994a). The reproducibility between three experiments is shown in Table 1, where the ratio between phosphatase activities and rates of uranyl uptake for the two strains are identical (1:6-fold).

Phosphatase localization was examined further on sections of cells using immunogold labelling (Fig. 2). Most of the enzyme was visible in the periplasmic space (Fig. 2a) and also associated with the outer membrane with, in some cells, a higher localization in the polar regions (Fig. 2b, arrowed), as seen previously in E. coli overexpressing alkaline phosphatase (Nesmeyanova et al., 1991). A higher concentration of immunogold label in late exponential phase cells was seen for both strains in accordance with the increased enzyme production reported in the mid-late exponential phase (Butler et al., 1991). Although some enzyme was apparent in the extracellular region, particularly in the overproducing strain (Fig. 2b), no evidence was obtained for the formation of outer-membrane vesicles as a mechanism for enzyme export as reported by Nesmeyanova et al. (1991), even though the specific activity of strain dc5c (946 units, Fig. 2b) was comparable to that of the overproducing E. coli (Nesmeyanova et al., 1991).

\section{Further studies of uranyl ion uptake by strains N14 and dc5c}

In accordance with previous studies (Macaskie et al., 1992), uranyl-unchallenged cells were indistinct when observed by electron microscopy; the cells were not stained (Fig. 3a, b). From the known phosphatase activity of a sample, it was possible to adjust the level of uranyl ion loading on the cells (given that these are correlated; Table 1) by the correct choice of sampling time from the uranyl-challenge solutions. Following uranyl accumulation, the cells became stained with an electron-opaque deposit which obliterated cellular detail (Fig. 3c, d). Occasionally broken cells were visible (Fig. 3e) showing clearly the cell-surface localization of the uranyl phosphate, the identity of which was confirmed as $\mathrm{HUO}_{2} \mathrm{PO}_{4} \cdot 4 \mathrm{H}_{2} \mathrm{O}$ using EDAX, PIXE and XRD, as reported previously (Macaskie et al., 1992; Yong \& Macaskie, 1995; Bonthrone et al., 1996). The localization of $\mathrm{HUO}_{2} \mathrm{PO}_{4} \cdot 4 \mathrm{H}_{2} \mathrm{O}$ was in accordance with the 

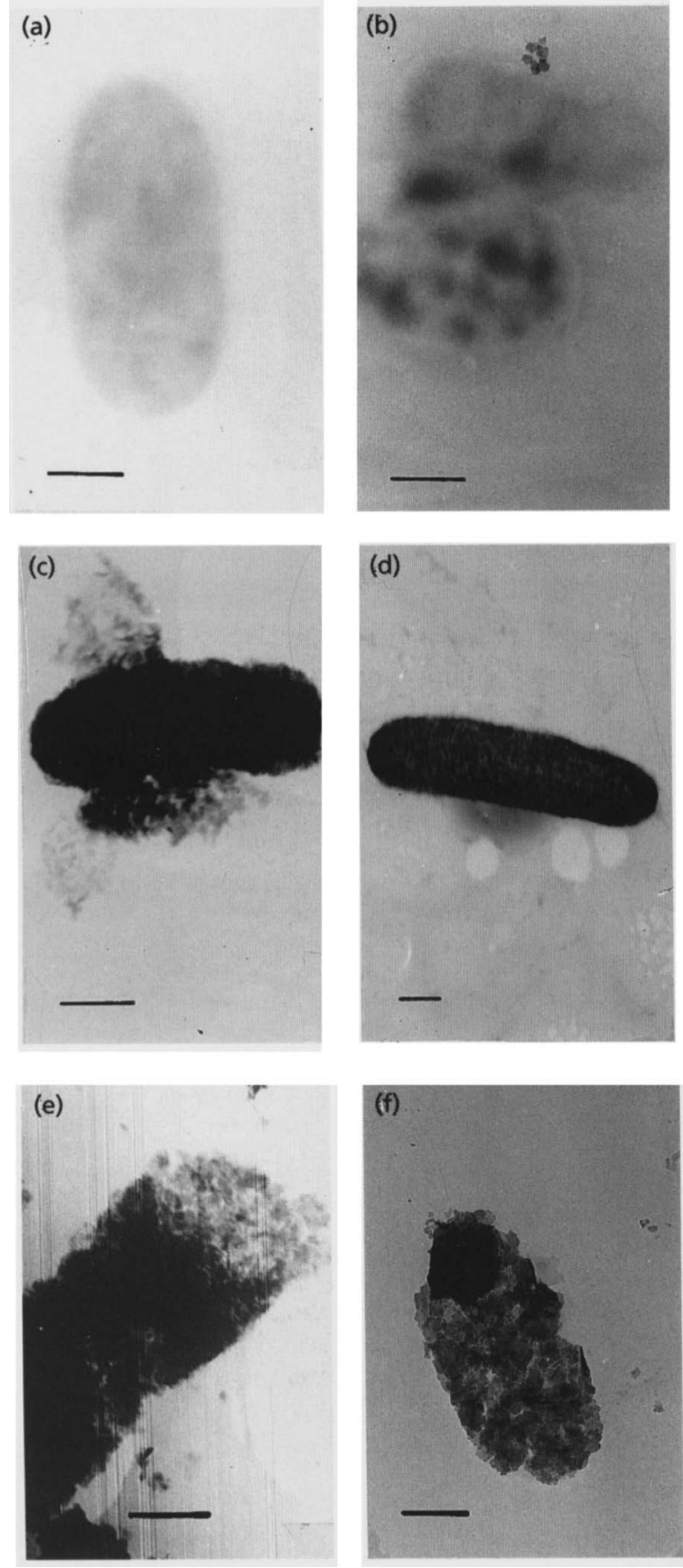

Fig. 3. Uranyl uptake by whole cells of strains $\mathrm{N} 14$ and dc5c. Cells were harvested in the mid-exponential phase $\left(O D_{600}=\right.$ $0.4-0.5)$ and resuspended in $2 \mathrm{mM}$ citrate buffer $/ 5 \mathrm{mM}$ glycerol 2-phosphate, either uranium-free $(a, b)$ or supplemented with $1 \mathrm{mM} \mathrm{UO} 2_{2}^{2+}(c, d)$. a and $c$, Strain N14 (phosphatase specific activity 188 units, uranyl loading was $155 \%$ of the bacterial dry weight in $c$ ); $b$ and $d$, strain dc5c (phosphatase specific activity 480 units, uranyl loading was $203 \%$ of the bacterial dry weight in d). In some cases broken cells were visible: (e) shows strain N14 (phosphatase specific activity 160 units, uranyl loading was $160 \%$ of the bacterial dry weight). Other cells in the cultures had dense polar deposits of uranyl phosphate (f). Bars, $500 \mathrm{~nm}$. cell-surface localization of the enzyme seen in Fig. 2. Some cells (Fig. 3f) had heavy polar deposits of uranyl phosphate, in accordance with the polar localization of the enzyme in some cells by immunogold labelling (Fig. 2). After drying and under examination in vacuo the uranyl-loaded cells appeared hard and crystalline. Attempts to visualize the precipitate on fully hydrated cells using AFM were unsuccessful. With wet preparations, movement of the cells under the probe gave very poor resolution. Partially air-dried samples gave clearly defined cells but the uranyl phosphate was not visible as clearly defined crystals.

\section{Events during the initial stages of uranyl ion deposition}

It was suggested previously that, for extensive metal accumulation, the phosphatase should be localized near to sites on the cell surface that can function as nucleation foci for initial complexation of the metal, and subsequent consolidation of crystal growth using $\mathrm{P}_{\mathrm{i}}$ liberated by the enzyme in the vicinity of the heavy metals (Macaskie et al., 1994a). Membrane phospholipids could fulfil this nucleation role. This was tested by examination of sections of cells which were interrupted during accumulation of uranyl ion (Fig. 4). Identical results were obtained for both strains at corresponding uranyl loadings. Little electron opaque material was associated with sections of uranyl-unchallenged cells (Fig. 4a); the sections were, in this case, stained with uranyl citrate after the incubation period to provide contrast. Initially the accumulated metal was visible as electron dense deposits following the tracks of the double membrane surrounding the cells (Fig. 4b), in accordance with the cell-surface pattern of uranyl deposition seen previously with Saccharomyces (Strandberg et al., 1981) and Pseudomonas (Strandberg et al., 1981; Marques et al., 1991), where the uptake of uranyl was rapid and largely membrane-localized. To date, there is no evidence from the literature that uranyl ion is able to enter the cytoplasmic compartment of living cells (probably attributable to the large size and stereochemistry of $\mathrm{UO}_{2}^{2+}$ and its associated hydroxyl groups; Weigel, 1986), even though uranyl ion induces formation of the chelating agents probably responsible for iron acquisition in Pseudomonas aeruginosa (Premuzic et al., 1985). Strandberg et al. (1981) noted that uranyl uptake occurred rapidly in $P$. aeruginosa, but the mechanism of translocation of $\mathrm{UO}_{2}^{2+}$ across the outer membrane and to the cytoplasmic membrane is still unknown. Following the initial membrane-associated deposition more extensive uranyl uptake occurred (Fig. 4c) and at high uranyl loadings (150-200\% of the bacterial dry weight) the deposited metal was clearly visible in a matrix of wall material that became detached from the cells, leaving wall-free cell 'ghosts' (Fig. 4d). Thus, the cell surface can be regarded as an immobilizing matrix for the enzyme. This could provide an explanation for the high metal loads seen without cessation of activity, or saturation [e.g. $9 \mathrm{~g}$ uranium $(\mathrm{g} \text { bacterial dry wt })^{-1}$; Macaskie, 1990]. 

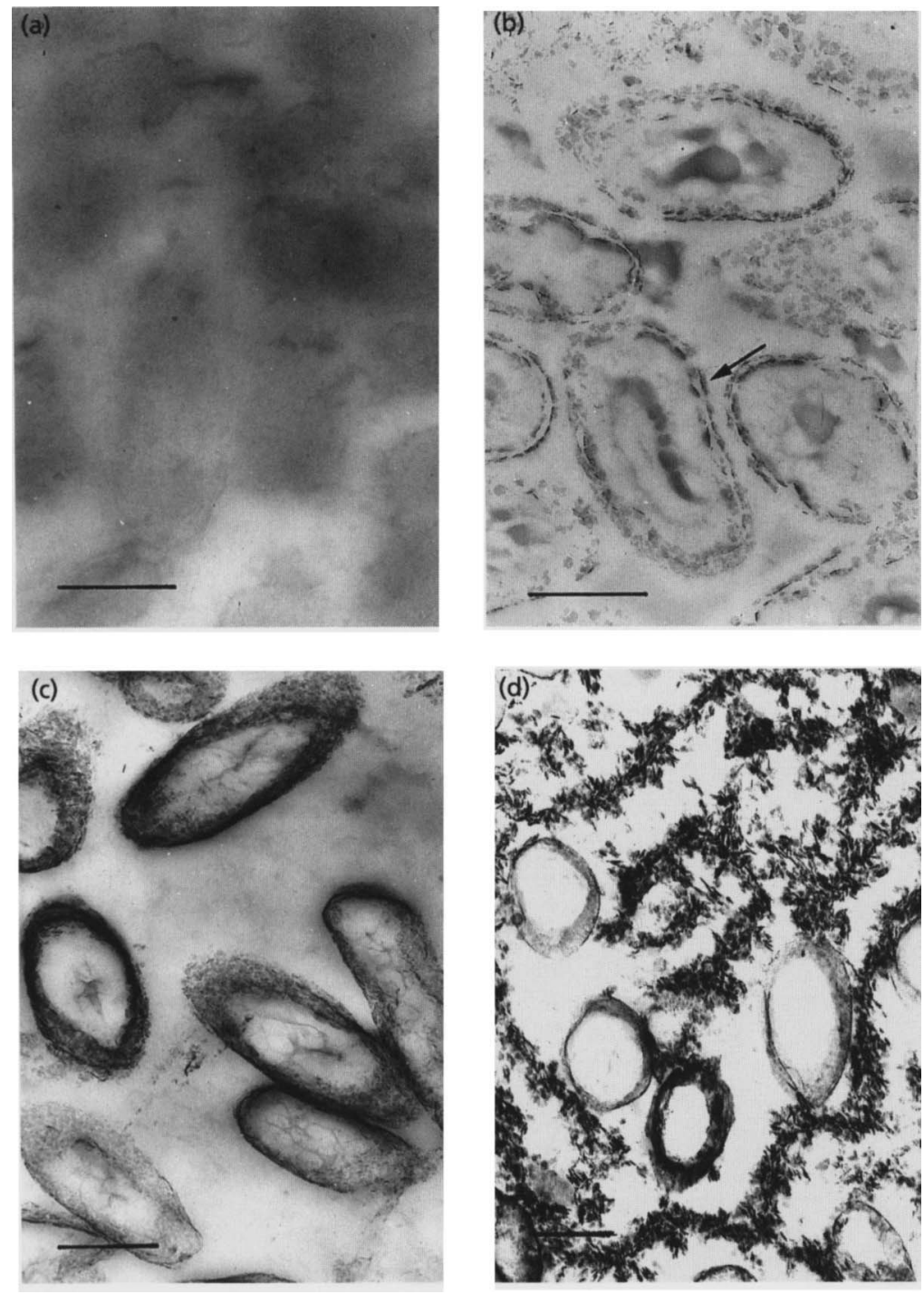

Fig. 4. Time course and localization of uranyl accumulation by strains $\mathrm{N} 14$ and dc5c. The results were similar for both strains; representative results from multiple sections of each strain are shown. Cells harvested in the mid-exponential phase $\left(O D_{600}=0.4-0.5\right.$, specific activities of $\mathrm{N} 14$ and $\mathrm{dc} 5 \mathrm{c}$ were 188 and 480 units, respectively) were challenged with $\mathrm{UO}_{2}^{2+}$ as described in the legend to Fig. 3, fixed with $1 \%$ glutaraldehyde and $1 \%$ paraformaldehyde, and embedded in LR White. Thin sections $(80-100 \mathrm{~nm})$ were examined. Uranylunchallenged cells (a) and cells loaded with $\mathrm{UO}_{2}^{2+}$ to 28 (b), 84 (c) and $165 \%$ of the dry weight (d). Bars, $500 \mathrm{~nm}$.
Since the cytoplasmic compartment does not appear to participate in uranyl phosphate deposition (Figs 3e and 4) and since the membranes appear to provide sites for metal deposition, metal uptake could occur by a phospholipid-based membrane surrounding entrapped enzyme. This was tested using column-immobilized and membrane-entrapped phosphatase in vitro.

\section{Phosphate release and metal uptake in vitro using immobilized phosphatase}

Initial tests in vitro utilized columns of $\mathrm{CNBr}$-immobilized phosphatase (see Methods) to test for the uptake of $\mathrm{UO}_{2}^{2+}$ from a $1 \mathrm{mM}$ solution supplemented with $5 \mathrm{mM}$ glycerol 2-phosphate. Phosphate release was observed from uranyl-unsupplemented solution but the enzyme was inactivated rapidly by $\mathrm{UO}_{2}^{2+}$, as confirmed by testing for phosphate release from substrate in metalfree flow subsequent to the initial uranyl-challenge, and was in accordance with metal toxicity tests where $\mathrm{UO}_{2}^{2+}$ gave $50 \%$ loss of phosphatase activity at a concentration of only $30 \mu \mathrm{M}$ (Jeong \& Macaskie, 1995). This short- lived activity was in contrast to columns containing whole cells, which retained phosphatase activity and uranyl removal over many weeks (Macaskie, 1990). It is likely that the enzyme held in the more protected periplasmic space matrix in whole cells is able to generate a protective localized layer of $\mathrm{P}_{i}$ before penetration of $\mathrm{UO}_{2}^{2+}$ across the outer membrane (note that uranyl uptake is not immediate, but is preceded by a short delay; Fig. 1).

Liposomes containing entrapped phosphatase were prepared according to published methods. The phosphatase ( $4.8 \mathrm{mg}$ protein before immobilization) had a specific activity of $11263 \mathrm{nmol} \mathrm{PNP} \min ^{-1}$ (mg protein) ${ }^{-1}$; that recovered in the liposome preparation (325 $\mathrm{mg}$ liposome $\mathrm{ml}^{-1}$ final concentration, containing $3 \mathrm{mg}$ protein $\mathrm{ml}^{-1}$ ) had a specific activity of $980 \mathrm{nmol}$ PNP $\min ^{-1}$ (mg protein $)^{-1}$. Thus the yield recovered in the liposomes was only approx. $9 \%$ of that incorporated into the preparation, and was consistent between liposome batches, within 10-15\%. Preliminary tests using liposome-entrapped phosphatase challenged with glycerol 

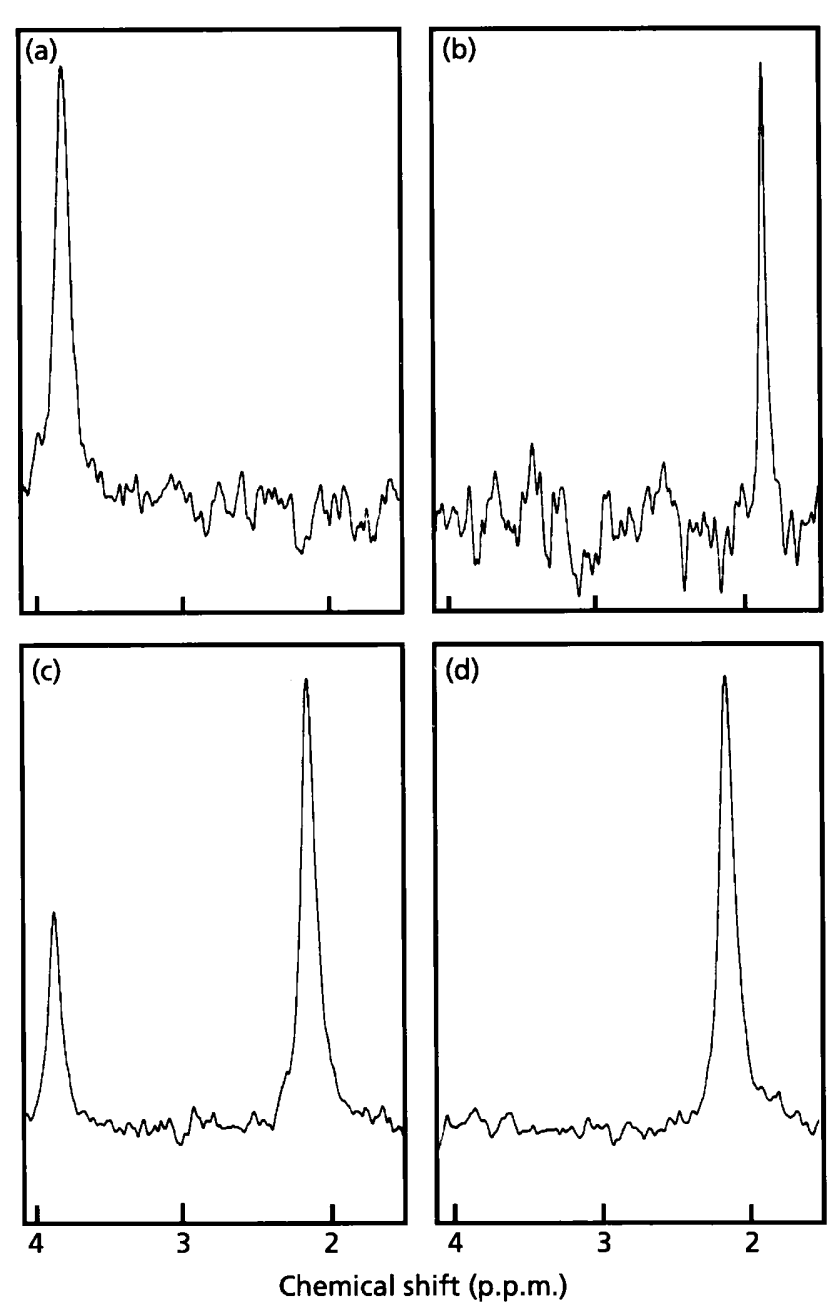

Fig. 5. A ${ }^{31} \mathrm{P}$ NMR study of phosphate release by Citrobacter whole cells and by liposome-entrapped phosphatase in the presence of $5 \mathrm{mM}$ glycerol 2-phosphate. The whole cells or liposomes were loaded into an NMR tube at a concentration calculated to give comparable rates of $P_{i}$ release (see text). Before initiation of the reaction, the peak corresponds to the chemical shift attributable to glycerol 2-phosphate (a). Purified phosphatase after reaction for 12 or 24 min gave a peak corresponding to the chemical shift of inorganic phosphate (b). Samples were withdrawn during the reaction supplemented with whole cells at 12 and 24 min ( $c$ and d, respectively) or supplemented with liposome-entrapped enzyme in the absence or presence of $1 \mathrm{mM} \mathrm{Cd^{2+ }}$, both of which gave spectra as in (c) and (d) (not shown).

2-phosphate confirmed $\mathrm{P}_{\mathrm{i}}$ release; the specific activity was $8.6 \mathrm{nmol} P_{i}$ released min $^{-1}$ (mg liposome preparation $)^{-1}$ (measured gravimetrically), corresponding to $96 \mathrm{nmol} \mathrm{m^{-1 }}$ (mg enzyme) $)^{-1}[0.09 \mathrm{mg}$ enzyme immobilized (mg dry wt of liposome material) $)^{-1}$. This is broadly similar to the specific activity of whole cells of strain N14 (e.g. legend to Fig. 2) and it is suggested that in terms of $P_{i}$ release per unit of mass of carrier the use of liposome-entrapped enzyme offers little or no advantage.

A representative time course in the presence of glycerol 2-phosphate showed substantial $P_{i}$ release which was unaffected by $\mathrm{Cd}^{2+}$ (approx. 8-9 $\mathrm{nmol} \mathrm{P}_{\mathrm{i}}$ released $\min ^{-1}$ $\mathrm{ml}^{-1}$ in each case), but was reduced by more than $75 \%$ in the presence of $\mathrm{UO}_{2}^{2+}$. Attempts to monitor total $\mathrm{P}_{\mathrm{i}}$ release by liposomes in the presence of $\mathrm{UO}_{2}^{2+}$ using ${ }^{31} \mathrm{P}$ NMR were unsuccessful, probably due to quenching by the paramagnetic uranyl ion. Phosphate release experiments therefore utilized 'NMR-silent' ${ }^{112} \mathrm{Cd}^{2+}$. Little signal was given by the liposome-bound phosphate groups (phosphatidylcholine) which were below the detection limit; indeed, $5 \mathrm{mM}$ glycerol 2-phosphate or $P_{i}$ was required for an acceptable signal to noise ratio (Fig. 5). Similar data were obtained in the absence and presence of $\mathrm{Cd}^{2+}$. This confirmed that degradation of glycerol 2-phosphate by liposomes with release of $P_{i}$ occurred within $24 \mathrm{~min}$, was comparable to the reaction seen with whole cells and was independent of the presence of $1 \mathrm{mM} \mathrm{Cd}{ }^{2+}$. Accurate quantification is difficult due to the low sensitivity of ${ }^{31} \mathrm{P}$ NMR, but the appearance of $P_{i}$ at the expense of substrate was shown clearly in all cases. $\mathrm{CdHPO}_{4}$ did not precipitate during the experiments (because the total phosphate was the same with and without Cd by NMR and was recovered as $P_{i}$ in the supernatant in each case: see above); possibly the $\mathrm{Cd}^{2+}$ was initially held as a complex with the phosphate groups of the phosphatidylcholine of the membrane. The presence of complexing ligands reduces the concentration of free metal (Hughes \& Poole, 1991).

In the phosphate release experiments (not shown) and in those using NMR, the liposomes precipitated in the presence of uranyl ion. Precipitated liposomes gave an $\mathrm{X}$-ray diffraction pattern indistinguishable from those published previously for cell-bound $\mathrm{HUO}_{2} \mathrm{PO}_{4}$ (Yong \& Macaskie, 1995; Bonthrone et al., 1996). There was no residual uranyl ion in solution by assay. Since the uranyl ion removed $(1 \mathrm{mM})$ exceeded the maximum concentration of $P_{i}$ liberated (up to $0.2 \mathrm{mM}$ ) it was assumed that $\mathrm{UO}_{2}^{2+}$ was deposited mainly onto the membrane phospholipid groups, in accordance with metal biocrystallization onto enzyme-free liposomes reported by Mann et al. (1986). Washed, uranyl-loaded liposomes gave negligible $P_{i}$ release subsequently. In contrast, liposomes previously exposed to $\mathrm{Cd}^{2+}$ had a phosphatase specific activity of (for example) $892 \mathrm{nmol}$ PNP $\min ^{-1}$ (mg dry $\left.w t\right)^{-1}$, i.e. a loss of activity of less than $10 \%$. $\mathrm{UO}_{2}^{2+}$ is more toxic to the phosphatase than $\mathrm{Cd}^{2+}$ (Jeong \& Macaskie, 1995) but it was not possible to conclude from these experiments whether activity was lost due to enzyme inhibition or to blockage by the accumulated metal.

\section{Examination of the metal-loaded liposomes using AFM and EM}

Attempts to examine native liposomes using AFM were unsuccessful. In the absence of metal the sticky liposomes gave distortion and dragging under the probe tip. Metal-loaded liposomes had a more granular appearance, but no structures were visible (not shown). Examination of the liposomes by EM after drying, but unstained, showed ill-defined oval vesicles of approx. $200 \mathrm{~nm}$ in length (Fig. 6a, arrowed). After uranyl- 

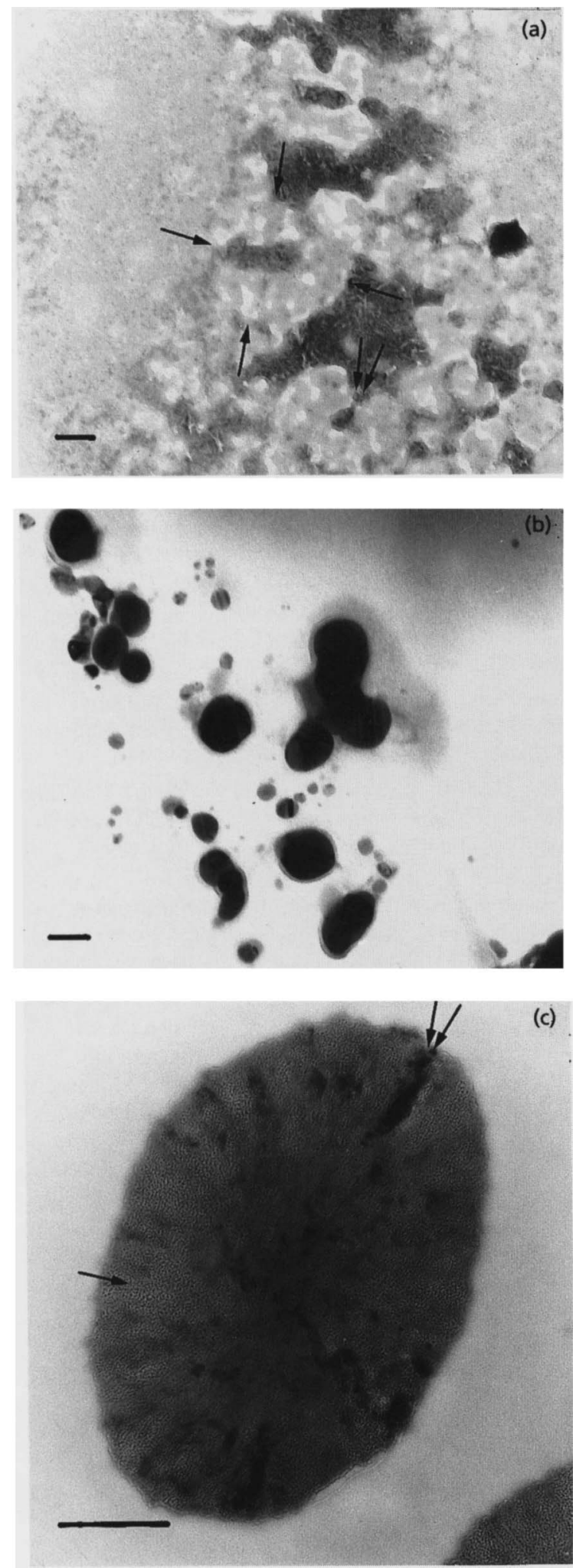

Fig. 6. EM study of uranyl ion accumulation by liposomes containing entrapped phosphatase. Liposomes were challenged with uranyl ion as described in Methods. Liposomes before (a) and following (b) uranyl-challenge; (c) shows detail of liposome following uranyl-challenge. Bars, $75 \mathrm{~nm}$ (a), $50 \mathrm{~nm}$ (b) and $20 \mathrm{~nm}(\mathrm{c})$. challenge the liposomes appeared as contracted, electron-opaque deposits with little structural definition (Fig. 6b). Closer examination (Fig. 6c) showed a granular pattern of uranium deposition (arrowed; possibly attributable to sorption onto the surface phospholipids) with localized areas of heavy deposition (double arrows). In native liposomes radial discontinuities are visible (Fig. 6a, double arrows), possibly providing access to the liposome interior.

\section{Conclusions, and implications for biotechnological metal removal}

This study establishes that metal accumulation as cellbound metal phosphate is mediated via a phosphatase, located periplasmically, in association with the outer membrane, and possibly also extracellularly. Uptake of $\mathrm{UO}_{2}^{2+}$ is initially at the sites of the double membranes bounding the cells and subsequently throughout the cell wall layers. Membrane phospholipids function as sites for uranyl phosphate crystallization in vitro but encapsulation of enzyme within liposomes confers no advantage over previous studies using these as metal sorbents per se (Mann et al., 1986). This is attributable to poor $\mathrm{P}_{\mathrm{i}}$ release by the liposomes in the presence of $\mathrm{UO}_{2}^{2+}$, probably attributable to blockage of sustained $\mathrm{P}_{i}$ release by the accumulated metal. In this respect the whole cells act as superior carriers of the enzyme, since the cell surface layers provide a framework for extensive uranyl phosphate deposition without fouling. A previous study has established that radio-killed cells retain the ability to accumulate metal (the phosphatase is radio-resistant; Strachan et al., 1991). Thus, dead cells can function as enzyme carriers, simultaneously providing phospholipid nucleation sites, together with the spatial infrastructure to hold the accumulated metal phosphate as large crystals, without blockage. The combination of these characteristics provides a novel system for the extensive removal and recovery of heavy metals from contaminated solutions unconstrained by the physiological requirements of the living cell.

\section{ACKNOWLEDGEMENTS}

B.C.J. acknowledges funding from the RRC at Myong Ji University, supported by Kyunggi Do and KOSEF. K.M.B. was funded by the EU, Contract No. BR2/0199/C. The authors wish to thank Dr G. Grime (Department of Nuclear Physics, University of Oxford) for PIXE analyses, Dr D. Goddard of the Company Research Laboratory, BNFL, for AFM, Mr D. Ruffles (School of Biological Sciences, University of Birmingham) for photography and Mr B. Martin (School of Biological and Molecular Sciences, Oxford Brookes University) for help in the immunolabelling.

\section{REFERENCES}

Barnes, L. J., Janssen, F. J., Sherran, J., Versteegh, J. H., Koch, R. O. \& Scheeren, P. J. H. (1991). A new process for the microbial removal of sulfate and heavy metals from contaminated wastes extracted by a geohydrological control system. Chem Eng Res Des 69A, 184-186. 
Barnes, L. J., Janssen, F. J., Scheeren, P., Versteegh, J. H. \& Koch, R. O. (1992). Simultaneous microbial removal of sulphate and heavy metals from waste water. Trans Inst Mining Metallurg C 101, 183-189.

Bonthrone, K. M., Basnakova, G., Lin, F. \& Macaskie, L. E. (1996). Bioaccumulation of nickel by intercalation into polycrystalline hydrogen uranyl phosphate deposited via an enzymatic mechanism. Nat Biotechnol 14, 635-638.

Butler, A. J., Hallett, D. S. \& Macaskie, L. E. (1991). Phosphatase production by a Citrobacter sp. growing in batch culture and use of batch cultures to investigate some limitations in the use of polyacrylamide gel-immobilized cells for product release. Enzyme Microb Technol 13, 716-721.

Diels, L., Dong, Q., Van der Lelie, D., Baeyens, W. \& Mergeay, M. (1995). The $c z c$ operon of Alcaligenes eutrophus $\mathrm{CH} 34$ : from resistance mechanism to the removal of heavy metals. $J$ Ind Microbiol 14, 142-153.

Hughes, M. N. \& Poole, R. K. (1991). Metal speciation and microbial growth; the hard (and soft) facts. J Gen Microbiol 137, 725-734.

Jeong, B. C. (1992). Studies on the atypical phosphatase of a metal-accumulating Citrobacter sp. DPhil thesis, University of Oxford, UK.

Jeong, B. C. \& Macaskie, L. E. (1995). PhoN-type acid phosphatases of a heavy metal-accumulating Citrobacter sp.: resistance to heavy metals and affinity towards phosphomonoester substrates. FEMS Microbiol Lett 130, 211-214.

Jeong, B. C., Kim, H. W., Owen, S. J., Dick, R. E. \& Macaskie, L. E. (1994). Phosphoesterase activity and phosphate release from tributyl phosphate by a Citrobacter sp. Appl Biochem Biotechnol 47, 21-32.

Kier, L. D., Weppelman, R. \& Ames, B. N. (1977). Resolution and purification of three periplasmic phosphatases of Salmonella typhimurium. J Bacteriol 130, 399-410.

Lloyd, J. R. \& Macaskie, L. E. (1996). Bacterial reduction and removal of technetium from solution. Proceedings of the $3 \mathrm{rd}$ International Conference on Minerals Bioprocessing and Biorecovery/Bioremediation in Mining. Big Sky, Montana, USA, 25-30 August 1996.

Lloyd, J. R., Cole, J. A. \& Macaskie, L. E. (1997). Reduction and removal of heptavalent technetium from solution by Escherichia coli. J Bacteriol 179, 2014-2021.

Macaskie, L. E. (1990). An immobilized cell bioprocess for the removal of heavy metals from aqueous flows. J Chem Technol Biotechnol 49, 357-379.

Macaskie, L. E. (1995). Copper tolerance, phosphatase activity and copper uptake by a heavy metal-accumulating Citrobacter sp. Microbios 84, 137-153.

Macaskie, L. E., Blackmore, J. D. \& Empson, R. M. (1988). Phosphatase overproduction and enhanced uranium accumulation by a stable mutant of a Citrobacter sp. isolated by a novel method. FEMS Microbiol Lett 55, 157-162.

Macaskie, L. E., Empson, R. M., Cheetham, A. K., Grey, C. P. \& Skarnulis, A. J. (1992). Uranium bioaccumulation by a Citrobacter $\mathrm{sp}$. as a result of enzymically-mediated growth of polycrystalline $\mathrm{HUO}_{2} \mathrm{PO}_{4}$. Science 257, 782-784.

Macaskie, L. E., Jeong, B. C. \& Tolley, M. R. (1994a). Enzymicallyaccelerated biomineralization of heavy metals : application to the removal of americium and plutonium from aqueous flows. FEMS Microbiol Rev 14, 351-368.
Macaskie, L. E., Bonthrone, K. M. \& Rouch, D. A. (1994b). Phosphatase-mediated heavy metal accumulation by a Citrobacter sp. and related enterobacteria. FEMS Microbiol Lett 121, 141-146.

Macaskie, L. E., Empson, R. M., Lin, F. \& Tolley, M. R. (1995a). Enzymatically-mediated uranium accumulation and uranium recovery using a Citrobacter sp. immobilized as a biofilm within a plug-flow reactor. J Chem Technol Biotechnol 63, 1-16.

Macaskie, L. E., Hewitt, C. J., Shearer, J. A. \& Kent, C. A. (1995b). Biomass production for the removal of heavy metals from aqueous solution at low $\mathrm{pH}$ using growth-decoupled cells of a Citrobacter sp. Int Biodeterior Biodegrad 35, 73-92.

Macaskie, L. E., Lloyd, J. R., Thomas, R. A. P. \& Tolley, M. R. (1996). The use of microorganisms for the remediation of solutions contaminated with actinide elements, other radionuclides, and organic contaminants generated by nuclear fuel cycle activities Nucl Energy 35, 257-271.

Macaskie, L. E., Yong, P., Doyle, T. C., Roig, M. G., Diaz, M. \& Manzano, T. (1997). Bioremediation of uranium-bearing wastewater: biochemical and chemical factors affecting bioprocess application. Biotechnol Bioeng 53, 100-109.

Mann, S., Hannington, J. P. \& Williams, R. J. P. (1986). Phospholipid vesicles as a model system for biomineralization. Nature 324, 565-567.

Marques, A. M., Roca, X., Simon-Pujol, M. D., Fuste, M. C. \& Francisco, C. (1991). Uranium accumulation by Pseudomonas sp. EPS-5028. Appl Microbiol Biotechnol 35, 406-410.

Mergeay, M., Nies, D., Schlegel, H. G., Gerits, J. \& Van Gijsegen, F. (1985). Alcaligenes eutrophus $\mathrm{CH} 34$, a facultative chemolithotroph displaying plasmid bound resistance to heavy metals. J Bacteriol 162, 328-334.

Nesmeyanova, M. A., Tsfasman, I. M., Karamyshev, A. L. \& Suzina, N. E. (1991). Secretion of the overproduced periplasmic PhoA protein into the medium and accumulation of its precursor in phoA-transformed Escherichia coli strains: involvement of outer membrane vesicles. World J Microbiol Biotechnol 7, $394-406$.

Neu, H. C. \& Heppel, L. A. (1965). The release of enzymes from Escherichia coli by osmotic shock and during the formation of spheroplasts. J Biol Chem 240, 3685-3692.

Nossal, N. G. \& Heppel, L. A. (1966). The release of enzymes by osmotic shock from Escherichia coli in exponential phase. $J$ Biol Chem 241, 3055-3062.

Pierpoint, W. S. (1957). The phosphatase and metaphosphatase activities of pea extracts Biochem J 65, 67-76.

Postgate, J. R. (1979). The Sulphate Reducing Bacteria. Cambridge: Cambridge University Press.

Premuzic, E. T., Francis, A. J., Lin, M. \& Schubert, J. (1985). Induced formation of chelating agents by Pseudomonas aeruginosa grown in the presence of thorium and uranium. Arch Environ Contam Toxicol 14, 759-768.

Roig, M. G., Manzano, T., Diaz, M. \& Pascual, M. J. (1995). Enzymically-enhanced extraction of uranium from biologicallyleached solutions. Int Biodeterior Biodegrad 35, 93-128.

Strachan, L. F., Jeong, B. C. \& Macaskie, L. E. (1991). Radiotolerance of phosphatases of a Citrobacter sp.: potential for the use of this organism in the treatment of wastes containing radiotoxic actinides. Proceedings of the 201st Meeting of the American Chemical Society Symposium: Biotechnology for Wastewater Treatment 31, 128-131.

Strandberg, G. W., Shumate, S. E., II \& Parrott, J. R. (1981). Microbial cells as biosorbents for heavy metals : accumulation of 
uranium by Saccharomyces cerevisiae and Pseudomonas aeruginosa. Appl Environ Microbiol 41, 237-245.

Tolley, M. R., Strachan, L. F. \& Macaskie, L. E. (1995). Lanthanum accumulation from acidic solutions using a Citrobacter sp. immobilized in a flow-through bioreactor. J Ind Microbiol 14, 271-280.

Volesky, B. (1990). Biosorption of Heavy Metals. Boca Raton, FL: CRC Press.

Weigel, F. (1986). Uranium. In The Chemistry of the Actinide
Elements, 2nd edn, pp. 169-442. Edited by J. J. Katz, G. T. Seaborg \& L. R. Morss. London: Chapman \& Hall.

Yong, P. \& Macaskie, L. E. (1995). Enhancement of uranium bioaccumulation by a Citrobacter sp. via enzymically-mediated growth of polycrystalline $\mathrm{NH}_{4} \mathrm{UO}_{2} \mathrm{PO}_{4}$. J Chem Technol Biotechnol 63, 101-108.

Received 16 December 1996; revised 5 March 1997; accepted 13 March 1997. 